\title{
AN INITIAL STUDY OF THE POLLUTION OF WATER IN INDUSTRIAL AREA SURROUNDING COASTAL ZONEOF NORTH JAKARTA, INDONESIA
}

\author{
Titia Izzati1 $^{1}{ }^{*}$, Kis Yoga Utomo ${ }^{2}$, Pebri Hastuti ${ }^{3}$, and Muhammad Fachrizal ${ }^{1}$ \\ ${ }^{1}$ Industrial Engineering Program, Engineering Faculty, Universitas Mercu Buana, 11650, Jakarta, Indonesia \\ ${ }^{2}$ Mechanical Engineering Program, Engineering Faculty, Universitas Krisnadwipayana, 13760, Jakarta, Indonesia \\ ${ }^{3}$ Economic Education Program, Economic Faculty, Universitas Negeri Medan, 20371, North Sumatera, Indonesia \\ E-mail:titia.izzati@mercubuana.ac.id, *tizzati@gmail.com, kyog14152004@gmail.com, pebrihastuti@ymail.com, \\ muahmmadfachrizal08@gmail.com
}

ABSTRACT: The purpose of this research is to know the result of measurement of acidity of ground water in North Jakarta, Indonesia. The method in this research is made by collecting ground water that is used for daily life in the city of North Jakarta. These research studies were conducted in residential and office area of North Jakarta to measure tap water and water offices as well as test the acidity levels ( $\mathrm{pH}$ ), Electrical Conductivity $(E C)$, Total Disolved Solids (TDS). Measurement results Groundwater in the North Jakarta area is alkaline $(\mathrm{pH})$ above 7. Industry and household activities and infrastructure development affect the contamination of rivers in North Jakarta due to industrial process, household waste and rain water in Jakarta area.

Keyword: acidity, electrical conductivity, industry, total dissolved solids, North Jakarta.

\section{INTRODUCTION}

Water is one of the most important elements on earth that is indispensable to life and all kinds of living things. water also has other functions such as for healing disease. it has a role in improving the quality of life of the community. Water settlement more exposed range of pollution from the environment. Human dependence on water is getting in line with the increase of population. Earth's predicate as "Planet Water" with 70\% of the earth's surface is covered by water is contrast to the state of the Earth that is facing water scarcity. Most of the water on earth is salt water and only about $2.5 \%$ only in the form of freshwater, and less than $1 \%$ that can be consumed, while the rest is water in the soil or in the form of ice in the polar regions[1].

Over time, the growth of high society followed by economic growth and development of industries[2, 3]. Many developer use the land and water and that causes the water scarcity increased. Water sources polluted because of waste generated by economic activities and industries, causing water quality that can be directly ingested and consumed by the population is getting less. Regional Water Company (PDAM) is a locally-owned enterprises (enterprises) that provide service and organizes benefit in the field of drinking water.

The physical requirements of water include: colorless, normal temperature, tastes tasteless, odorless, clear or not turbid and does not contain solids $[4,5]$.The degree of acidity $\mathrm{pH}$ is also one part of the chemical quality that can degrade the water quality the neutral.pH of water is in the range of 6.8 to 7.0 if the $\mathrm{pH}$ of water is below $\mathrm{pH} 7$ then the water is in an acid state.Indonesian republic government regulation no. 82 of 2001 on Water Quality Management and Water Pollution Control states that what is meant by water is all water contained in, above or below the surface of the soil, including in terms of surface water, groundwater, rainwater, seawater located on land[6].

Water quality in Jakarta is in critical condition. Most groundwater, both in the free aquifer and the distressed aquifer, is not meeting the standard of drinking water quality required by the government. Water quality in North Jakarta is influenced by industrial waste, transportation waste, and household waste such as detergent[6-8].

The environment effects of waste and waste management of indutries and its area in Indonesia, especially in big cities have been studied in advance [9-19]. However, the needs of open space research is limited. The research study about the green area also limited, such as in Cibubur, close to East Jakarta that held by social welfare and youth people in collaboration with the Ministry of Young and Sport Of Republic Indonesia[20-22].

Furthermore, the problem identification in this research is how to balance the $\mathrm{pH}$ of ground water in North Jakarta area, and the influence of environmental condition at groundwater $\mathrm{pH}$ level in North Jakarta. The purpose of this research is we can test or analyze some qualitative and quantitative qualities of physical and chemical qualities of groundwater.

\section{RESEARCH METHODS}

\section{Measuring Procedures}

The tool used to perform water quality analysis is a multimeter (waterproof multimeter) to measure $\mathrm{pH}$, EC, TDS, and water temperature [23, 24].

\section{Sampling}

The materials used are water settlement/plumbing, office water/ industry in 20 points accordance with the area to be studied.

\section{Time}

This research was conducted for 2 months ( 8 weeks), September 3, 2017 to November 4, 2017. 


\section{RESULTS and DISCUSSION}

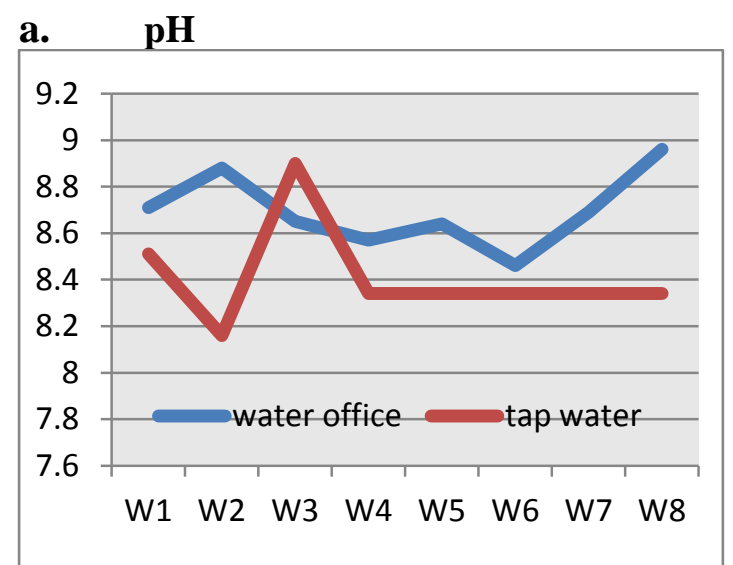

Figure 1. Graph of pH

The $\mathrm{pH}$ results for tap water in the North Jakarta residential area showed an average value of 8.4.the decrease in week 2 . the highest $\mathrm{pH}$ value at week 3 . $\mathrm{pH}$ value was stable at week 5 to week 8 , alkaline state.

The $\mathrm{pH}$ value for office water in the North Jakarta area shows the value is not as stable as up and down each week. The highest $\mathrm{pH}$ value at week $8 \mathrm{pH}$ value 9.0.the lowest ph value at week $6 \mathrm{pH}$ value 8.4.

Based on the Regulation of the Minister of Health No. 416 / MEN.KES / PER / IX / 1990 on Water Quality and Condition Monitoring[25], it shows the alkaline state and it is consider to be used for daily life. The regulation states the $\mathrm{pH}$ of water standard for health consumption is in the range of 6.5 to 8.5 .

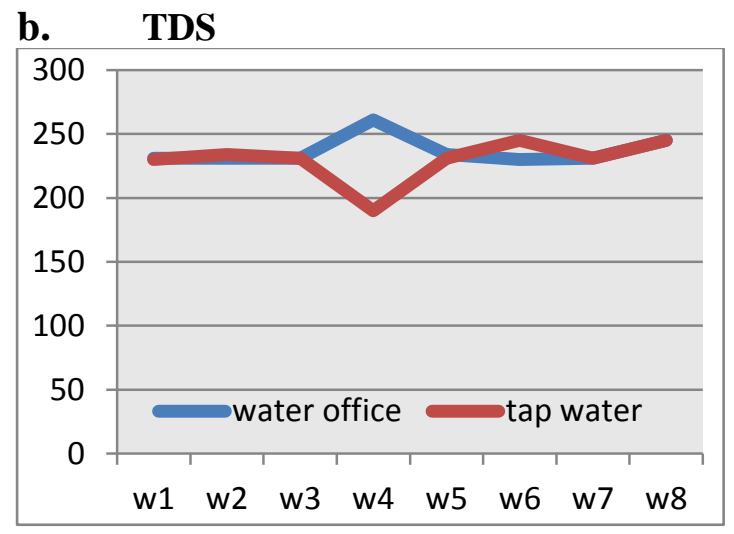

Figure 2. Graph of TDS

Based on the graphs abouve, the TDS results for tap water in the North Jakarta residential area show an average value of 230.the highest TDS value at week 8. TDS values are as stable as in week 1 to week 3 and a decrease at week 4 becomes unstable.

The TDS results for tap water in the North Jakarta residential area showed an average value of 237.the highest TDS value at week 4. TDS value was stable at week 1 to week 3 and decreased at weeks 6 and 7 .

\section{c. $\quad$ EC}

The EC yield for tap water in the North Jakarta residential area shows an average of 544.the highest EC value at week 8 . The lowest EC value at week 1. is increment in every week from week 1 to 8 .

The EC yield for tap water in the North Jakarta residential area shows an average of 204.the highest EC value at week 4. The lowest EC value at week 3 . becomes up and down in every week.

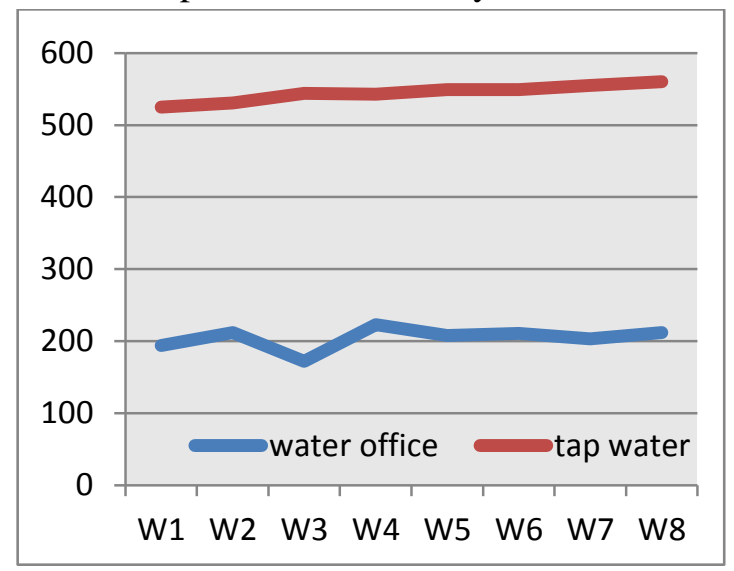

Figure 3. Graph of EC

\section{EXPLANATION OF RESULTS OF MEASUREMENT}

The result of $\mathrm{pH}$ measurement in North Jakarta shows average $\mathrm{pH}$ above 8 . the measurement result shows that the water in North Jakarta is on average is basa.hal this is because in North Jakarta area there is water contamination which caused many society still waste waste which contain chemicals directly to the soil causing water pollution. The effects of factory waste should be turned off so that the environment is not polluted[26].

North Jakarta has a wild growing population and developed rose buildings. Due to contamination from waste produced by so many stakeholders, the water becomes unhealthy for consumption by people [27, 28 ], especially with the reduction of open space and the growth of pollution[22]. In order to maintain the purity of the water content and the availability of clean water it is necessary to balance the natural ecosystem and preserve the environment from the damage caused by industrial pollution, pollution, household waste and excessive water use. According to Law no. 32 RI in 2009 (UUPPLH)[29] environmental pollution is the entry of living things, substances, energy and other components into the environment by human activities so that beyond the existing raw quality.[30] 


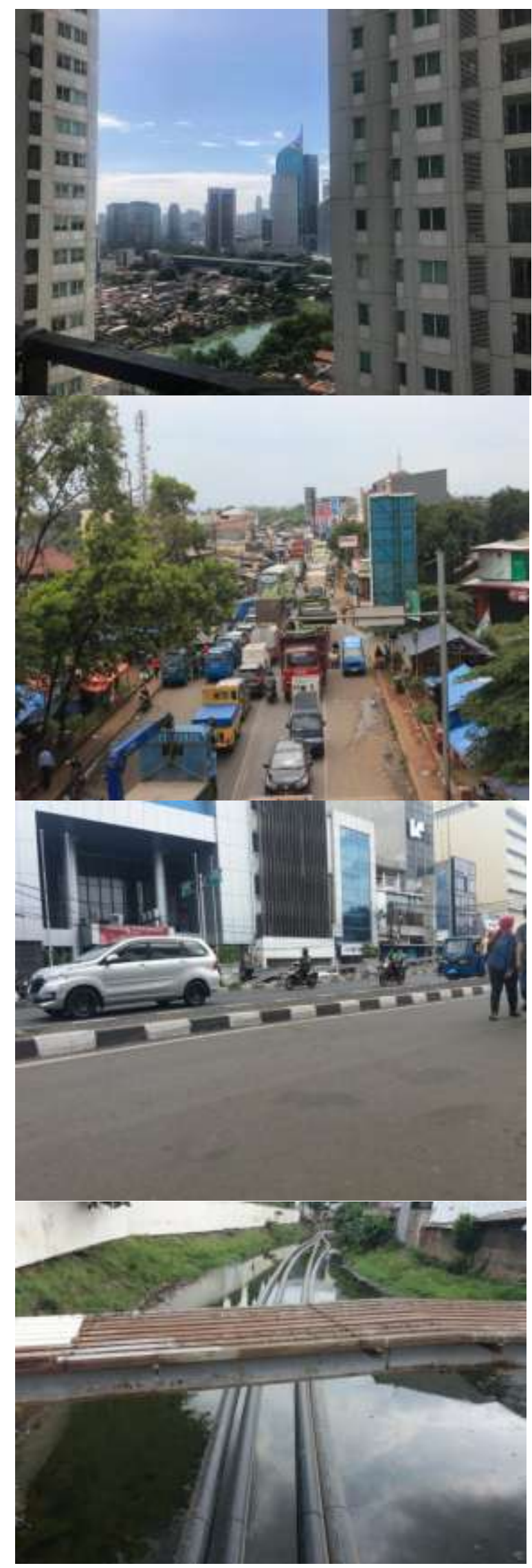

Figure 4. Part of industries in North Jakarta

\section{CONCLUSION}

1. The measurement results of tap water and offices indicate that water has a $\mathrm{pH}$ above 7 means the water is alkaline.

2. The higher the TDS value in tap water or office water means that the water is already contaminated by chemical substances.

3. Industrial and residential environments greatly affect the value of $\mathrm{pH}, \mathrm{EC}$, and TDS

\section{ACKNOWLEDGEMENTS}

This research was supported by The Students of Chemistry and Enviromental Study Classes Reg 1 \& 2: 16066/Gasal/2017-2018 and The Students of Environmetal Engineering Study Class Reg 2: 82011/Gasal/2017-2018, Universitas Mercu Buana Kampus D, Indonesia.

We gratefully acknowledge the funding from USAID through the SHERA program Centre for Development of Sustainable Region (CDSR).

\section{REFERENCE}

1. Chang, M., 2006, Forest hydrology: an introduction to water and forests. 2006: CRC press.

2. INDONESIA, P.R., Editor 2007, Undang-undang Republik Indonesia Nomor 26 Tahun 2007 tentang Penataan Ruang, Jakarta, from Jakarta

3. Indonesia, U.-u.R., Editor 1992, Perumahan dan Permukiman, Kementrian Negara Republik Indonesia: Jakarta, from Kementrian Negara Republik Indonesia

4. Effendi, H., 2003, Telaah kualitas air, bagi pengelolaan sumber daya dan lingkungan perairan. 2003: Kanisius.

5. Fardiaz, S., 1992, Polusi air dan udara. 1992: Kanisius.

6. Stauffer, J., 2013, The water crisis: Constructing solutions to freshwater pollution. 2013: Routledge.

7. Caviglia-Harris, J.L. and R.T. Melstrom, 2015. Airing Your Dirty Laundry: A Quick Marketable Pollution Permits Game for the Classroom. The Journal of Economic Education, 46(4): p. 412-419.

8. Hocking, M.B., 2016, Handbook of chemical technology and pollution control. 2016: Elsevier.

9. Izzati, T., 2016. An Initial Study Of The Air Pollution Through Rainwater In An Industrial Area Of Bekasi. World Chemical Engineering Journal, 1(2).

10. Izzati, T., 2016. An Initial Study Of The Air Pollution Through Rainwater In An Industrial Area Of Cikarang, West Java, Indonesia (A Case Study). Science International, 28(4).

11. Izzati, T., 2017. Water Quality Analysis Of Residential And Industrial Areas In Bogor, West Java, Indonesia. Science International, 29(2): p. 37-370.

12. Izzati, T., et al., 2016. An Initial Study Of Laundry Industrial Effects To The Water Pollution In East Jakarta. IOSR Journal of Environmental Science, Toxicology and Food Technology 10(9): p. 35-37.

13. Izzati, T., et al., 2016. An Initial Study Of Industrial Area's Effects For The Air Pollution Through Rainwater In East Jakarta. IOSR Journal of Mechanical and Civil Engineering, 13(4): p. 159-162. 
14. Izzati, T., et al., 2016. An Initial Study Of Laundry Industrial Effects To The Water Pollution In Bekasi. IOSR Journal of Business and Management, 18(8): p. 109-111.

15. Amalia, M., B.P. Resosudarmo, and J. Bennett, Editors. 2013, The Consequences of Urban Air Pollution for Child Health: What does Self Reporting Data in the Jakarta Metropolitan Area Reveal?,

16. Baum, G., et al., 2015. Local and regional impacts of pollution on coral reefs along the Thousand Islands north of the megacity Jakarta, Indonesia. PloS one, 10(9): p. e0138271.

17. Resosudarmo, B.P. and L. Napitupulu, 2004. Health and economic impact of air pollution in Jakarta. Economic Record, 80(s1): p. S65-S75.

18. Zain, A.F., et al., 2015. The detection of urban open space at Jakarta, Bogor, Depok, and TangerangIndonesia by using remote sensing technique for urban ecology analysis. Procedia Environmental Sciences, 24: p. 87-94.

19. Izzati, T., 2017. An Initial Study of the Water Pollution Analysis at Residential, Office Building and Industrial Area's in Bogor. World Chemical Engineering Journal, 1(4): p. 31-34.

20. Izzati, T., et al., 2015. Social Welfare Programs For Young Society In Indonesia. Science International, 27(5): p. 4715-4717.

21. Izzati, T., et al., 2015. An Education Profile Of Indonesian Youth In 2009-2013. Science International, 27(2): p. 1457-1460.
22. Izzati, T. and Y. Poerwanti, 2014. Enhancing The Productivity And Multifunctionality Of Open Space Using Simple Techniques In Green Buildings. Science International, 26(2): p. 689-690.

23. Izzati, T., 2017, Kimia dan Praktikumku. Panduan Praktikum Kimia Sederhana Bagi Mahasiswa Teknik Mesin. 2017, Jakarta: Pustaka Mandiri.

24. Izzati, T., 2017, Kimia dan Praktikumku. Panduan Praktikum Kimia Sederhana

Bagi Mahasiswa Teknik Industri. 2017, Jakarta: Pustaka Mandiri.

25. Indonesia, M.K.R., Editor 2016, Peraturan Menteri Kesehatan No. 416 Tahun 1990 Tentang: Syaratsyarat Dan Pengawasan Kualitas Air,

26. Siahaan, N.H.T., 2004, Hukum Lingkungan dan Ekologi Pembangunan. 2004: Erlangga.

27. Damanhuri, E., 2010. Informal collectors of recyclable waste and used goods in Indonesia. POLICIES FOR SOUTHEAST AND EAST ASIA: p. 71.

28. Dick, H.W. and P.J. Rimmer, 1998. Beyond the third world city: the new urban geography of South-east Asia. Urban Studies, 35(12): p. 2303-2321.

29. AIR, P.P.T.P.K. And D.P.P. AIR, 2002. PERATURAN PEMERINTAH REPUBLIK INDONESIA NOMOR 82 TAHUN 2001 TENTANG PENGELOLAAN KUALITAS AIR DAN PENGENDALIAN PENCEMARAN AIR PRESIDEN REPUBLIK INDONESIA.

30. Komaruddin, N., 2008. Penilaian Tingkat Bahaya Erosi di Sub Daerah Aliran Sungai Cileungsi, Bogor. Agrikultura, 19(3). 